\title{
Six Sigma For Sustainability In Multinational Organizations
}

Abdullah AlSagheer, Hamdan Bin Mohammed e-University, Dubai UAE

\begin{abstract}
The Six Sigma model provides various kinds of sustainability to companies in terms of quality enhancement, zero defect level, market share enhancement, optimal production level and financial returns. Multinational companies are more orientated toward implementation of Six Sigma than small scale locally held companies. Numerous larger companies have so far implemented Six Sigma including 3M, Caterpillar, Merrill Lynch, Bank of America, Amazon.com, DHL, SGL group, Dell, Ford Motor Company, DuPont, McGraw Hill Companies and HSBC group. Implementation of Six Sigma requires considerable cost and effort in terms of human resource training and reformulation of business processes. This study is an attempt to find what kind of sustainability motivates multinational companies to invest in Six Sigma. Sustainability identified includes social sustainability, environmental sustainability, and economic sustainability. With the aid of interviews, a constant comparison study is conducted in order to find the most prevalent type of sustainability offered by Six Sigma. A sample is drawn from multinational companies which have already implemented Six Sigma in their operations. The findings suggest that multinational companies implement Six Sigma in order to attain economic sustainability through various means such as market share, customer base, and social sustainability.
\end{abstract}

Keywords: Six Sigma; sustainability; multinationals; economic sustainability; zero defect level; financial sustainability

\section{INTRODUCTION}

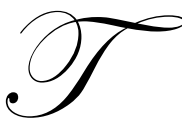

he world is witnessing a reformed shape of business, an approach more focused on quality and customer care. The traditional concept of supplier orientation has shifted to customer orientation and traditional meaning of quality has also changed. Quality management, total quality management, zero defect level, lean management, continuous improvement and Six Sigma have evolved over the period of time to meet quality requirements of customers. Each having a slighter different and updated focus of quality, Six Sigma is the most advance approach. Six Sigma is a quality management initiative that takes the methodological approach based on data attempting to eliminate the defects to minimize standard deviation to desired level of quality (Six Sigma, 2010). The study is focused to find sustainability that Six Sigma brings in multinationals. Small businesses, due to their small scale and low organized processes confront difficulties while implementing six sigma processes. Present study finds the sustainability that six sigma provides to larger multinational organizations in terms of society, environment and financial return.

\section{Background Of Study}

Initiated by Motorola, Six Sigma has largely been adopted by number of multinational, larger scale companies. A few to mentioned includes 3M, Merrill Lynch, Bank of America, Amazon.com, DHL, SGL group, Dell, Ford Motor company, DuPont, McGraw Hill Companies, HSBC group, United States Army and many others (Gupta, 2005). It is pertinent to notice that mostly multinational and larger companies have adopted Six Sigma (Wiele, Iwaarden and Power, 2010). Literature and actual implementation of Six Sigma largely reflects the fact that multinational companies are more inclined towards adoption of Six Sigma as it produces multifaceted sustainability. Core reasons of this adoption is that multinational afford higher cost of training, higher technical expertise requirement and more advance processes (Gupta, 2005). 


\section{Statement Of The Research Problem}

Multinational organizations adopts six sigma as it offer them sustainability and diversity however, it is important to learn what type of sustainability does six sigma provide to the companies. The core research question to be addressed is what kind of sustainability is largely provided by Six Sigma in multinational companies. The core question is supported by several secondary questions such as is it in terms of financial success, corporate social responsibility, market share or business's repute for best practices? Does the core objective of Six Sigma is to bring financial success? How companies define sustainability and what do they want to achieve through Six Sigma?

\section{Purpose And Significance Of The Study}

The study is aimed to drill down into concept of sustainability provided by Six Sigma. It is important to learn how quality management and advanced quality approaches are helping companies to improve their performance and efficiency. The study is a guideline for companies that have not ventured for Six Sigma. Many multinational companies such as IBM, Microsoft and Royal Dutch Shell are using their customized quality approach (Schwandt and Marquardt, 2000). The study will ardently provide a basis of comparison between Six Sigma companies and customized quality approaches for future research. Moreover, it is significant from Six Sigma companies view point by looking into possible sustainability that Six Sigma can add to their businesses.

\section{Review Of The Literature}

A wide variety of literature is present which draws on Six Sigma, sustainability and sustainability brought by Six Sigma in multinational companies in different perspectives. Six Sigma has a history of twenty four years and theorists have widely discussed its different aspects. The literature initially defines how Six Sigma works for multinational companies and what the term sustainability ideally reflects. In later part, the literature reviews the sustainability actually brought by Six Sigma in companies and the core aim of adopting Six Sigma in different companies.

\section{Six Sigma For Quality Management}

Six Sigma is highly effective implementation of proven quality principles and techniques. The approach works for virtually error free business performance. In Six Sigma, the company's performance is measured by the sigma level of businesses process (Pyzdek and Keller, 2009). An approach focused on establishing world class performance bench marks provides road map for attaining zero error level. Apparently Six Sigma is associated with the enhancing quality of good and services, nevertheless, it brings efficiency and effectiveness in processes throughout the organization (Truscott, 2003).

Six Sigma approach marvelously improves quality as it objectively looks into quality measurement. Henderson and Evans (2000) McCarty and Fisher (2007) stated that Six Sigma make measurement possible through its multi dimensional statistical model. The model is primarily focused on three aspects i-e sigma statistics, sigma measure and performance benchmark however no element specifically identifies the level of sustainability (Truscott, 2009). Turscott (2009) further exemplifies the Six Sigma implementation by looking at following daily life examples:

Table 1: Six Sigma Implementation from Daily Life

\begin{tabular}{|c|c|c|}
\hline Process sigma value & Expectation of Time without electricity & Aircraft accidents \\
\hline 2 & $207 \mathrm{~h}$ & 8 per 10 flights \\
\hline 3 & $45 \mathrm{~h}$ & 24 per 100 flights \\
\hline 4 & $4 \mathrm{~h}$ & 25 per 1000 flights \\
\hline 5 & $9 \mathrm{~min}$ & 9 per 10,000 flights \\
\hline 6 & $8 \mathrm{sec}$ & 12 per million flights \\
\hline
\end{tabular}

Source: Truscott (2009) 
Six Sigma works on principles of continuous improvement; Coronado and Antony (2002) resembles the Six Sigma as a loop which begins with defining the goals of improvement activity i-e benchmarking of quality services and leads to measuring of existing system. In Six Sigma, measuring the existing system is often termed as gap analysis (Antony, 2006). The next component of Six Sigma loop works with identifying the ways to remove the gap and improving the present system (Thareja, 2006). If Six Sigma loop stops at continuous improvement, it will more likely consider as total quality management (Khan, 2003).

\section{Sustainability}

The other core element of Six Sigma implementation is the sustainability which it brings to the organization. Generally understanding sustainability, sustainability is best defined by world commission on environment and development (1987) stating that sustainable development is development that meets the need of present without compromising the ability of future generation to meet their own needs. Fricker (1998) defined sustainability as vision of future that provides a road map while focusing on certain set of ethical and moral values which may guide the actions of an entity. Looking sustainability in details, it mainly focuses on three aspects i-e economic growth, social progress and environmental protection (Munier, 2006).

Sustainability involves people, capital resources, natural resources, environment and institution. Fricker (1998) further added that sustainability is not merely an end result of processes rather it continuous seeking of quality behavior. An organization is said to be sustainable if its people are willing to bring a change and embrace the change ultimately leading toward sustainable organizational design (Shrivastava and Director, 1995).

In an organizational perspective particularly, sustainability refers to the value addition from Six Sigma. The dimension of sustainability includes variation elimination, control on new processes, statistical controls, reduced complexity, precision, accuracy and effectiveness in business process (Giardina, 2006). An addition in traditional Six Sigma is lean Six Sigma which primarily focuses on improved process flow (Reiling, 2008). Due to difference of focus, the perspective for sustainability also varies. In Six Sigma, the sustainability refers to utmost standardization with zero defects whereas lean Six Sigma emphasize sustainability as identification of value, defining value stream, determining flow, defining pull and improving process in every business function such as marketing, finance and management (Taghizadegan, 2006).

\section{Sustainability Achieved Through Six Sigma}

Multinational companies have adopted Six Sigma for variety of purposes however, the core goal was to attain financial sustainability through improved processes and better work flow (Poudlove, Moxham and Boaden, 2008) however, the financial success is achieved through multidimensional quality improvements (Mahadevan, 2010). General Motors reduced its disposal costs by $\$ 12$ million through kanban system; an integral part of Six Sigma. Similar to this, Robins Air Force Base, C-130 paint shop reduced tools material and equipment by $39 \%$ and $\$ 373,800$ in direct operating savings (Giardina, 2006).

3M was among few companies which initiated to adopt Six Sigma. 3M upgraded to lean Six Sigma and its purpose was to attain environmental stability. The company is pioneer in use of lean Six Sigma methods and tools to improve operations and quality. In first step, the company trained its 100,000 employees for Six Sigma in order to attain the operational sustainability. 3M achieved multi facet results such as improvement in energy efficiency from $20 \%$ to $27 \%$ and reduction in waste index to net sales from $25 \%$ to $30 \%$. All these achievements are aimed toward attaining environmental sustainability and operational sustainability. Till 2005, savings from the lean Six Sigma project was amounted to $\$ 1$ billion which was made possible by reducing pollution, improving workflow, equipment redesign, process ramification and product reformulation (3M Lean Six-Sigma and Sustainability, 2010).

Byrne (2007) also asserts that companies implement Six Sigma to drive the innovation. The first five years of lean Six Sigma helped many companies to improve their results such as attained by Caterpillar. Weber (2004) also quotes Caterpillar as achiever from Six Sigma. In September 2004, Caterpillar was \$20 billion Company and Caterpillar was aimed to increase the revenues by $\$ 10$ billion in first decade of lean Six Sigma implementation. Weber (2004) contrasts with Byrne (2007) in the context that caterpillar wanted to attain the innovation 
sustainability. According to Weber (2004), caterpillar was focused on achieving financial stability. The company's top management has highlighted that Caterpillar management such as CEO has claimed that Six Sigma was the important contribution toward increase in sales of caterpillar. Six Sigma is also driving the continuous improvement culture in the company and business is gaining efficiency in all respects (Weber, 2004).

Hilton (2008) identifies several companies such as Motorola, General Electric, Dell Computer, Dow Chemicals, Wal-Mart and Honeywell who implemented Six Sigma and attained measurable results. General electric saved $\$ 8$ billion after implementing Six Sigma in three years and Wall-Marts is looking for savings of $\$ 1$ billion from lean Six Sigma (Leahy, 2000).

\section{RESEARCH METHODOLOGY}

\section{Study Design}

Decision to implement of Six Sigma comes from organizational leaders. Since every organization is unique and has its own requirements, therefore company's internal management can determine the potential benefits to be achieved by the Six Sigma (Bertels, Rath \& Strong, 2003). Defining objectives for the company and preparing employees to accept change occurred through Six Sigma is responsibility of top management and leaders. According to Pande (2003), Six Sigma lies in the vision of top management and only they can decide what sustainability they want from Six Sigma.

On these grounds, the study seeks direct interaction with top management about sustainability desired from Six Sigma. The survey method provides researcher with an ease of open communication and allows sharing of ideas and thoughts. Surveys are considered best when opinion and ideas of people are important in shaping a conclusion (Groves, Fowler, Couper, Lepkowski and Eleanor, 2009). The study adopted cross section survey method as its core research methodology. In survey, interview tool was used to collect data directly from top management of multinational companies. Cross sectional survey are used to collect information at a single point in time and helps to establish the relationship between two entities (Babbie, 1990). Brief structured interviews were conducted to collect the data from participants.

\section{Participants}

Participants were selected using purposive sampling. Purposive sampling provides an opportunity to select participants on a specific criterion which fits to the purpose of study (Teddlie and Tashakkori, 2009). For present study, interviewees were selected on number of criteria such as listed below:

- $\quad$ The participants belong to a multinational company which has already implemented Six Sigma.

- $\quad$ The participant works on multinational on any key managerial position directly associated with decision making. Such participants include chief operating officers, chief executive officers, senior finance managers, chief information manager, information technology head, information technology specialist and senior management.

- Participant has been working in the organization before the Six Sigma was implemented in the company.

\section{Data Collection And Data Analysis}

Since it was difficult to visit such participants personally due to geographical constraints, interviews were conducted on telephone where personal visit was not possible. After getting the list of multinational companies who have implemented the Six Sigma, the information tentative participants were collected using official websites and Chamber of Commerce websites. The contact information, permission and appointment for an interview were also obtained via telephone. The interviews could not be recorded as permission was not granted however; notes were taken during the interview and were later converted into text manually. The text was later analyzed using software Weft QDA and patterns were obtained. Constant comparison approach was used to compare the interview transcript and to obtain the patterns. According to Glaser and Strauss (1967), constant comparison approach helps to develop a 
theory about the phenomenon. The constant comparison is made through development of codes and subsequently, a theory is developed.

The interviews were structured and comprised of 15-20 twenty minute each. In all, forty two participants from different companies were interviewed. The participants includes senior finance managers, chief executive officers, IT managers, chief operating officers and in some cases directors of companies also. The participants companies include Maple Lead Foods, Pakistan International Airlines, Pakistan State Oil, Starwood Hotels and Resorts Worldwide, Deere and Company, Bank of Montreal, McGraw Hill Companies and Vodafone.

\section{Findings And Analysis}

Telephonic and face to face interviews were conducted to collect the data from participants. In all forty two participants were interviewed which included executives and managers. The stratification of participants on basis of their designation is provided below:

Table 2: Stratification of Participants on Designation

\begin{tabular}{|l|c|c|}
\hline & Participants & \%age Participation \\
\hline Senior Finance Managers & 12 & $29 \%$ \\
\hline Chief Executive Officers & 7 & $17 \%$ \\
\hline IT Managers & 14 & $33 \%$ \\
\hline Chief Operating Officers & 5 & $12 \%$ \\
\hline Directors & 4 & $10 \%$ \\
\hline Total & 42 & $100 \%$ \\
\hline
\end{tabular}

The interviews were brief and structured (Appendix A). Primarily the interviews were focused to know what type of sustainability motivates the multinational companies to invest in Six Sigma. Using the constant comparison approach, the interviews text was analyzed for patterns. Two level coding was performed using Weft QDA as the purpose was to find which type of sustainability is acquired through Six Sigma. Several codes were found which were emerged. Redundant codes were merged to derive constant flow of information. Primary and secondary research questions are addressed through several themes discussed heere

\section{Core Objective Of Six Sigma}

Secondary research questions inquiring core objectives of Six Sigma were addressed through themes such as competition, zero defect level and financial success. As reflected by most of the, Six Sigma is implemented to stay competitive with other companies. Participants concluded that multinational companies needs to build corporate repute which increases their market share and Six Sigma is nowadays used as tool to reflect that company is taking endeavors for improving quality. This at first hands improves the competitive position of the company. Regional Finance Manager of Vodafone asserted that "The impacts of Six Sigma are long term and may be seen afterwards however; the company instantly start attaining repute after implementation of advance quality model". COO of Maple Lead Foods was also of the view that "To remain competitive in market, continuous improvement in every aspect is necessary. Six-Sigma is also aimed to help us in enhancement in our market image in eyes of competitors" Vice President (Finance) of Bank of Montreal endorsed the same by stating "Other larger banks have already implemented similar models which has raised customers' expectation. We are aimed to attain better market position by implementing an optimal service quality model".

Second prevailing theme for core objectives of Six Sigma was quality improvement. "Six-Sigma really helps to improve quality, we can see the difference. Processes are now more efficient and speedy" stated by IT manager of Starwood Hotels. CEO of Pakistan International Airlines asserted that "The model has helped to stay efficient and had reduced our effort in day to day activities. We are now more competent for offering quality solutions to our passengers and to our suppliers". COO of Pakistan State Oil stated the fact "Six Sigma has reduce our effective time to market and we had a desire to attain so from this model implementation". 
Third objective as extracted from most of interviews was the ability of Six Sigma to improve financial position of the company. It is evolved from the interviews that almost all companies are highly profit oriented and Six Sigma is adopted as a tool to attain financial success. Most of the company's executives reflected that Six Sigma is not merely adopted for financial success however, the responses can be considered as attempt to act in socially desirable manner. Executives of large multinational companies may not always admit that their specific endeavor is merely for profits. Reflection about company's high concern toward profits can harm its repute as socially responsible company (Stocké, 2003). CEO of Pakistan State Oil endorsed that" We understand Six-Sigma reduces material wastage and improves supply chain activities. Ultimately, it leads to overall cost reduction". COO of Maple Leaf Foods also asserted that "Six-Sigma do cost to use however, we expect a positive return in terms of market repute ultimately translated in financial success". Senior Vice President (Finance) of Deere and Company stated, "It is important to look all projects from financial perspective. We considered the cost and benefit analysis of Six Sigma as fundamental step for deciding on the project".

\section{How Companies Understand Sustainability}

Secondary question pertaining to sustainability was explained with themes such as financial stability, improvement in quality, optimal productivity, social responsibility, environmental protection and value addition to the company. The most prevalent theme emerged for sustainability is financial success and optimal productivity. As reflected by all participants, the primary meaning of sustainability is financial success and optimal production with minimum defects. Multinational companies consider financial success as the foremost sustainability to be achieved through zero defect level. In opinion of CEO of Pakistan International Airline "A company can only be socially responsible when it is financial sustainable. For me, sustainability is the financial success which enables PIA to be sustainable in other areas too". IT Manager of McGraw Hill Companies highlighted the fact that "when I think of sustainability, I think of higher financial return earned on investments of shareholders. Finance manger of John Deer and Company however, considered value addition as true sustainability by stating "We are sustainable when our products are able to generate value for our company". Endorsed by director of Starwood Hotels, "We are sustainable when are able to offer highest with the lowest sources, this means Starwood is sustainable in terms of services and in its corporate framework".

The other prevalent theme about sustainability was environmental protection and corporate social responsibility. Director of Deere and Company defined sustainability as "We are sustainable when we are harmless to society and its stakeholders". IT manager of Bank of Montreal highlighted the same fact "Sustainability is an attempt to be productive for the society and for its members".

\section{Sustainability Attained Through Six Sigma}

The literal meaning of sustainability identified by participants is different from the sustainability desired to be attained through Six Sigma. While analyzing the interviews, the most prevalent theme of sustainability attained through Six Sigma was zero defect level, optimal production and financial success. The primary research questions of study i-e what kind of sustainability is largely provided by Six Sigma in multinational companies. The multinational companies mostly reflected that Six Sigma has helped them in improving production and services ultimately translated into financial success. The primary research question was aimed to find what kind of sustainability has actually been provided by implementing Six Sigma. This has further been identified by secondary research question about core aim of Six Sigma and understanding of sustainability by multinational companies.

"Six Sigma has helped us achieve financial success" identified by CEO of Deere and Company. Further elaborated by CEO of Deere and Company, Six Sigma has helped us in improving human resource functions, customer services and low cost. Ultimately, all these types of sustainability are translated into financial success. "Our employee satisfaction has increases which have helped to reduce material wastage and become process efficient. Reduced employee turnover and reduced manufacturing cost. Due to Six-Sigma implementation has considerably helped out to increase financial viability". Finance Manger of Vodafone highlights the sustainability achieved through implementation of Six Sigma "Vodafone market share has increased as well as its financial returns. Six-Sigma has offered us financial sustainability as well as market sustainability". 
As revealed in the present study, Six Sigma sustainability bears a multifaceted concept for organizations. Sustainability is primarily offered by Six Sigma however, every company takes the Six Sigma from a different perspective. It is not only the perspective which differs, rather the organizations adopts several ways to reach to a single sustainable point which is common in all organizations. Organizations' understanding of sustainability is contrasting with the requirements of Commission on Environment and Development (1987) definition of sustainability. Multinational organizations are working for material sustainability instead of focusing on developing sustainability for creating conductive environment for future changes (Ethier, 1986). Sustainability as defined by Shrivastava and Director (1995) has not been addressed by multinational companies in its fullest. Multinational organizations' core aim to adopt Six Sigma was either to remain competitive with the other companies or to attain zero defect level along with financial sustainability. In addition, the sustainability is taken by multinational companies in terms of effectiveness in business process which are capable enough to be translated into financial success (Giardina, 2006). The concept of Giardina (2006) and Taghizadegan (2006) are closely aligned and both fit to the present understanding of organizational sustainability to be achieved through Six Sigma. Sustainability as identified by organizations holds multiple meaning and multinational organization use Six Sigma to escalate from one sustainability to other such as optimal production to higher market share and ultimately into financial success (Muneir 2006). Actual sustainability as reflected by $3 \mathrm{M}$ experience and Robins Air Force Base attained financial sustainability through Six Sigma. 3M saved $\$ 1$ billion by implementing Six Sigma by the way of product reformulation, process ramification and equipment redesign (Giardina, 2006).

Amalgamating secondary and prime research question about sustainability provided by Six Sigma, it is evident from the study that multinational companies are more concerned with multidimensional sustainability however; the financial sustainability is mostly desired sustainability. Multinational companies are focused on achieving financial stability using different sustainability routes such as value addition, process improvement, human resource process improvement and market sustainability. The financial sustainability is the ultimate goal however, achieved through various type of sustainability.

\section{SUMMARY AND CONCLUSIONS}

Six Sigma is a multidimensional approach for improving process efficiency and attaining sustainability. Six Sigma has traditionally been adopted by multinational companies due to several reasons such as higher concern for quality, higher availability to resources and competitive business environment. Initially Six Sigma was introduced by Motorola however; soon it became an advance model for improving quality. Larger companies such as $3 \mathrm{M}$, Deere and Company, Caterpillar, Bank of America and McGraw Hill Companies are already sustainability through Six Sigma. The study has an aim to find what kind of sustainability is being obtained by implementation of Six Sigma. Several theorists have identified several types of sustainability few including process improvement, financial sustainability, market share, value addition, corporate reputation- all broadly covered under social repute, environment protection and economic growth. The study directly interacts with participants and adopts qualitative research methodology to address the subject matter. Under qualitative study, survey design and interview tools are used for making constant comparison analysis of all interviews. With constant comparison, several themes were emerged to address the primary and secondary research question.

Primarily, Six Sigma is multifaceted and holds several aspects variably been considered by multinational companies. Organizations are less concerned with environment protection, moderately concerned with social repute such as competitive position in eyes of competitors and highly concerned with economic growth. The economic growth widely covers financial returns attained through different routes such as increase in market share, economies of scale production, minimum input cost and low employee turnover. Multinational companies' ultimate objective is to increase financial returns by identifying market share increase, customer base enhancement, zero defect level and competition as secondary objectives. For multinational companies, aim and sustainability of Six Sigma varies as most of companies considers Six Sigma as a way to meet competition however, sustainability is associated with financial success. The combination of sustainability and Six Sigma ultimately translated into sustainable financial return which helps the company to increase its market competitiveness. 


\section{Implications For Future Research}

Six Sigma is not a new issue nevertheless; the issue has mainly been addressed by developed counties. Mostly, the organizations that have implemented Six Sigma belong to developed nations. In few cases, companies of small underdeveloped countries have implemented Six Sigma and have reaped significant benefits from implementation of Six Sigma. The study identifies such companies and reflects on sustainability provided such as financial returns; markets share increase, environmental protection, zero defect level and others. In this way, it is a guide for small companies which have still not implemented Six Sigma considering it as an expensive way to quality. The study provides a guide to companies about the benefits attained through Six Sigma and serve as guidelines for companies who have not yet implemented Six Sigma.

Present study is an initial research on sustainability provided to multinational companies. The study is under limited scope as it collects data from CEOs of only few companies. A large number of companies and their top executives are still untapped to describe several types of sustainability provided. In addition to this, sustainability with respect to industry and type of business can also be identified to customize the Six Sigma for specific businesses. The study is a subject measurement of sustainability generally drawn on all type nevertheless, leaving a significant margin to calculate financial sustainability provided to these companies.

The study is a base for future studies as first step of identification of top most sustainability provided by Six Sigma has been completed. The base study can be utilized for identification and statically measurement of market, financial, environmental and social sustainability provided. In addition, a comparison can be made between multinational and domestic or small vs. larger scale companies for the financial return improvement or customer base enhancement.

\section{AUTHOR BIOGRAPHY}

Dr. Abdullah AlSagheer is an Assistant Professor of Management at the e-School of Quality and Business Management at the Hamdan Bin Mohammed e-University. He is teaching undergraduate courses level such as TQM Implementation, Capstone Project. In addition, he is teaching graduate courses level such as Strategic Management of Innovation and Technological change. Dr. AlSagheer has PhD in Education and Human Resource Studies specialized in Interdisciplinary Studies (Industrial and Human Recourse Management Engineering) and M.Ed Education and Human Resource Studies specialized in Interdisciplinary Studies (Industrial and Human Recourse Management Engineering) from Colorado State University (CSU). He received Master of Science in Electrical Engineering specialized in Integrated Systems \& Strategic Project Management. His undergraduate degrees were Bachelor of Science in Computer Engineering and a double major in Bachelor of Science in Electrical Engineering from California State University Long Beach (CSULB). Dr. AlSagheer research focuses in strategic management, capstone courses, entrepreneurship and leadership, total quality management, ergonomics and human factor engineering, curriculum development, human resource management, management training, teamwork, innovation strategies, engineering management, and industrial engineering.

\section{REFERENCES}

1. 3M Lean Six Sigma and Sustainability. 2010. United Stated Environmental Protection Agency. Available [Online] http://www.epa.gov/lean/studies/3m.htm [Accessed December 08, 2010].

2. Antony, J. 2006. 'Six sigma for service processes', Business Process Management Journal, Vol. 12 No. 2, pp. $234-248$

3. Babbie, E. 1990. Survey research methods. Wadsworth Pub. Co.

4. Bertels, T., Rath \& Strong. 2003. Rath \& Strong's six sigma leadership handbook. John Wiley and Sons.

5. Byrne, G., Lubowe, F., and Blitz, A. 2007. 'Using a Lean Six Sigma approach to drive innovation', Strategy \& Leadership, Vol. 35 No. 2, pp. $5-10$

6. Coronado, R.B. and Antony, J. 2002. 'Critical success factors for the successful implementation of six sigma projects in organizations', The TQM Magazine, Vol. 14 No. 2, pp 92 - 99

7. Ethier, W. 1986. 'The Multinational Firm', The Quarterly Journal of Economics, Vol 101 No. 4, pp- 805834 
8. $\quad$ Fricker, A. 1998. 'Measuring up to sustainability', Futures, Vol 30 No. 4. pp-367-3

9. Giardina, A. 2006. Sustainability and Lean Six Sigma. Available [Online] http://proceedings.ndia.org/JSEM2006/Wednesday/Giardina.pdf [Accessed December 10, 2010 ].

10. Gupta, P. 2005. The Six Sigma performance handbook: a statistical guide to optimizing results, McGrawHill Professional, pp- 15-19

11. Glaser, B. G., \& Strauss, A. L. 1967. The discovery of grounded theory: Strategies for qualitative research. Chicago: Aldine

12. Groves, R., Fowler, F., Couper, M., Lepkowski, K., and Singer, E. 2009. Survey methodology: Volume 561 of Wiley series in survey methodology. John Wiley and Sons.

13. Henderson, K. H. and Evans, J. R. 2000, 'Successful implementation of six sigma: benchmarking General Electric company', Benchmarking: An International Journal, Vol. 7 No. 4, pp 260- 281

14. Hilton, H. 2008. Managerial Accounting, $7^{\text {th }}$ ed. Tata McGraw-Hil.

15. Khan, J. 2003. 'Impact of total quality management on productivity', The TQM Magazine, Vol. 15 No. 6, pp. $374-380$

16. Leahy, T. 2000. 'In search of perfection with Six Sigma', Business Finance, Vol. 5 No. 1, pp-72-74.

17. Mahadevan, B. 2010. Operations Management: Theory and Practice. Pearson Education India.

18. McCarty, T., and Fisher, K. 2007. 'Six sigma: it is not what you think', Journal of Corporate Real Estate, Vol. 9 No. 3, pp. $187-196$

19. Munier, N. 2006. Introduction to Sustainability: Road to a Better Future, Springer, pp-10-15

20. Our Common Future: Report of the World Commission on Environment and Development, Our Common Future, Chapter 2: Towards Sustainable Development. 1987. UN Documents. Available [Online] on http://www.un-documents.net/ocf-02.htm [Accessed November 28, 2010].

21. Pande, K. 2003. The Six Sigma Way. Tata McGraw-Hill.

22. Proudlove, N., Moxham, C., and Boaden, R. 2008. 'Lessons for Lean in Healthcare from Using Six Sigma in the NHS,' Public Money \& Management, Vol. 28 No. 1, pp. 27-34,

23. Pyzdek, T., and Keller, P. 2009. The Six Sigma handbook: a complete guide for green belts, black belts, and managers at all levels, McGraw Hill Professional, pp-34-38

24. Reiling, J. 2008. Lean Versus Six Sigma: What's the Controversy? What the Difference? Available [Online] http://www.articlesbase.com/business-articles/lean-versus-six-sigma-whats-the-controversy-whatthe-difference-595677.html\#ixzz17Y3zDWRW [Accessed December 20, 2010].

25. Schwandt, D., and Marquardt, M. 2000. Organizational learning: from world-class theories to global best practices, St. Lucie Press, pp-120-31

26. Six Sigma. 2010 Available [Online] on http://www.managementhelp.org/quality/sixsigma/six-sigma.htm [Accessed November 27, 2010].

27. Shrivastava, P., and Director, S. 1995. 'Creating sustainable corporations', Business Strategy and the Environment, Vol. 4 No. 3, pp-154-165.

28. Stocké, V. 2001. Socially desirable response behavior as rational choice: the case of attitudes towards foreigners. Sonderforschungsbereich.

29. Taghizadegan, S. 2006. Essentials of lean Six Sigma. Butterworth-Heineman.

30. Teddlie, C., and Tashakkori, A. 2009. Foundations of mixed methods research: integrating quantitative and qualitative approaches in the social and behavioral sciences. SAGE Publications Inc.

31. Thareja P, 2006. 'A Total Quality Organization through People; Part 5, People as Change Agents', Foundry, A Journal of Progressive Metal Casters, Vol. 18 No. 5, Sept/Oct.

32. Truscott, W. 2003. Six sigma: continual improvement for business: a practical guide Referex Engineering, Butterworth-Heinemann, pp-15-35

33. Wiele, T., Iwaarden, J., and Power, D. 2010. 'Six Sigma implementation in Ireland: the role of multinational firms', International Journal of Quality \& Reliability Management, Vol. 27 No. 9, pp- 1054 66. 


\section{NOTES}

